\title{
Response of Three Dry Season Varieties of Tomato (Lycopersicon esculentum Mill.) from Northern Nigeria to Different Watering Regimes
}

\author{
*Adeleke, Martina T. V. Onoriode Charity O. \\ Department of Plant Science and Biotechnology, Rivers State University, Nkpolu, Port Harcourt, Nigeria
}

\begin{abstract}
The production of commercial tomato is influenced by both genetic and environmental factors such as soil, climate and water. A greenhouse experiment was conducted to ascertain the effects of different watering regimes on the physiology of three varieties of dry season tomatoes cultivated in northern Nigeria: The Gboko variety cultivated in Benue state, the Pankshin variety cultivated in Plateau state and the Zaria variety cultivated in Kaduna state. The varieties were planted on the same day in a Randomized Complete Block Design, with three varieties and five watering treatments in intervals of: one, two, four, six and eight days respectively. Analysis of variance of the physiological parameters used - leaf area and plant height of the different watering regimes indicate that they varied significantly $(p>0.05)$ for Zaria, but not for Gboko and Pankshin. Zaria was the poorest with every eight day watering regime, whereas Gboko and Pankshin tolerated better a wide range of watering régime.
\end{abstract}

Keywords: Watering regime, Tomato, variety, climate

DOI: $10.7176 / \mathrm{FSQM} / 84-02$

\section{Introduction}

Tomato (Lycopersicon esculetum) is one of the most widely consumed vegetables in the world today. There are a lot of tomato cultivars, and they are adapted to a wide climate range. Different varieties of tomato are found in Nigeria. Oladitan and Oluwasemire (2018) revealed that yield differences among tested varieties indicate the need for selection of suitable varieties for the sowing seasons. Tomato production in Nigeria is mainly concentrated in the northern part of the country, however there is some production in the middle belt and south-western part of the country as well. The variation in the varieties found in these different geographical locations of the country is a result of the different climatic factors which work in consonance, such as temperature, humidity, rainfall, sunlight and time of the year (Agele et al., 1999, 2002; Odeleye and Odeleye, 2001). Some of the different varieties of tomato in the Nigerian market are: Zaria seed, Gboko, PankchinUTC, Beske, RomanVFN, and Ibadan local.

The production of tomato in relation to demand is generally low in Nigeria, and this can be attributed particularly to the unfavorable weather condition for it during a greater part of the year in most parts of the country. In the humid west to southern regions, production of the crop has been limited majorly by climatic factors, which include low temperature, high humidity and high rainfall (Agele et al., 2002; Akanni and Ojeniyi, 2007; Adekiya and Agbede, 2009; Ewulo et al., 2008). Temperature plays a major role in the productivity of tomato; high temperature aid maturation of tomato (Ploeg and Heuvelink, 2005). Tomatoes are long day and day neutral plant, and long day lengths are found in the northern part of the country. For tomato, best growth and yield were obtained under a photoperiod of 14 hours (Agele, et al., 2002).

Only during the harmattan period, November to March is good tomato abundant, and virtually all of this comes from the northern part of the country. Tomato cultivation was rapidly adapted to by dry season farmers in the north, and constitutes a major element in the internal trade in horticultural products. Outside this period, good quality fresh tomato with rich puree is scarce and expensive in the country. Hence, there is the need to increase the availability of fresh tomato to meet up with the high demand for this commodity, particularly during the wet season, in Nigeria.

The production of most annual crops can be sustained only through irrigation which play a vital role in ensuring continuity of production and good quality crops. The cool-dry season, where irrigation facilities exist, is the preferred environment for tomato production (Oiganji et al., 2013).

Water requirement of a crop can be expressed as evapotranspiration (ET). This is the amount of water transpired by the plant and evaporated from the soil surface. ET are affected by temperature, light intensity, wind, humidity, crop cover and crop growth stage. For optimum crop production, the water use (ET) must be replenished by irrigation or rainfall (Kuscu, et al., 2014). Tomato is known to be grown by irrigation in the northern part of Nigeria during the dry season. Tomato varieties produced at the peak of the dry season usually contain more pulp/puree and less moisture content. Water deficits occurring during ripening stage increased values of soluble solid content, dry matter content, total sugar, total acidity, lycopene and total carotene (Turhan et al., 2016; AbdelRazzak et al., 2016).

This study therefore seeks to find out the effect of different watering regimes on some physiological parameters of three dry season Tomato varieties grown in Northern Nigeria viz. Zaria, Pankshin and Gboko. 


\section{Materials and Method}

The experiment was conducted at the green house of the Department of Applied and Environmental Biology, Rivers State University, Port Harcourt.

Three different tomatoes varieties: Gboko variety cultivated in Benue State, Pankshin variety cultivated in Plateau State and Zaria variety cultivated in Kaduna State were purchased from the fruit garden market, in Port Harcourt. The Gboko and Zaria variety seed were collected in December and the Pankshin variety seed was collected in February.

Soil was collected from the Rivers State University farm site. A sample of the soil was analyzed (sandy loam soil). The soil was bagged in $2 \mathrm{~kg}$ capacity polyethylene planting bags.

The tomato seeds were separated from the flesh and air-dried at room temperature for 2 days.

A total of 45 planting bags of soil were collected, 15 bags for each variety and each bag weighed up to $1.5 \mathrm{~kg}$ (bag and soil). Each planting bag was watered with $100 \mathrm{ml}$ of water and the seed were planted $2 \mathrm{~cm}$ deep in each bag. The experiment was a randomized complete block design (RCBD) with three tomato varieties and five watering treatments viz.

Once every day- E1D

Once in 2 days - E2D

Once in 4 days - E4D

Once in 6 days - E6D

Once in 8 days - E8D

Germination counts were made and measurements were taken of plant height and leaf area over time. The data was analyzed using ANOVA to test for significant difference between treatments.

\section{Result}

Sprouting of the seed was observed first on the fourth day in at least one bag per treatment of the three varieties, but no growth was noticed at all in the eight days watering of the Zaria variety. It however grew later. The morphology of the leaves of the three varieties of tomato show some variation in the leaf blade. The edges of the leaves of Zaria and Gboko are quite serrated, and have tiny leaves in between the bigger ones on a branch (Fig. 1). The leaves of Pankshin on the other hand are larger with more rounded, less serrated edges, and no small leaves in-between the big ones.

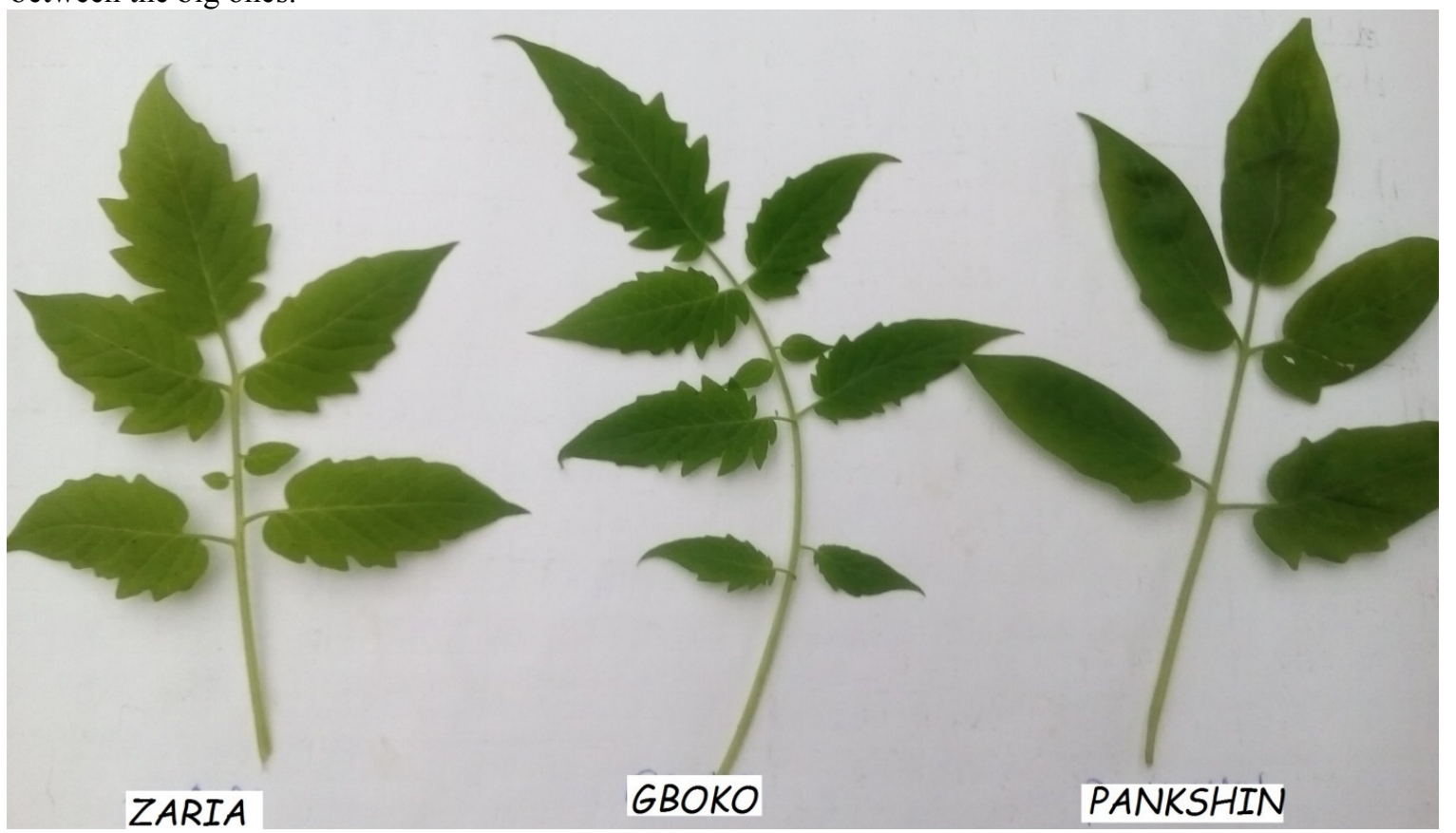

Fig. 2: Leaves of the three varieties

In plant height and leave area, Gboko variety is the tallest of the three (Fig. 3 and 7), though this is not significantly so. The "E2D" watering treatment gave the highest plant height for all three varieties, and this is followed closely by "E4D" watering in Gboko and Pankshin varieties. Pankshin "E6D" watering treatment competes favorably with E2D and E4D watering treatments. Of all three varieties, only Zaria showed some significant difference in the plant height for the different watering treatments; and Zaria was lowest in plant height with "E8D" watering treatment.(Fig. 7) 


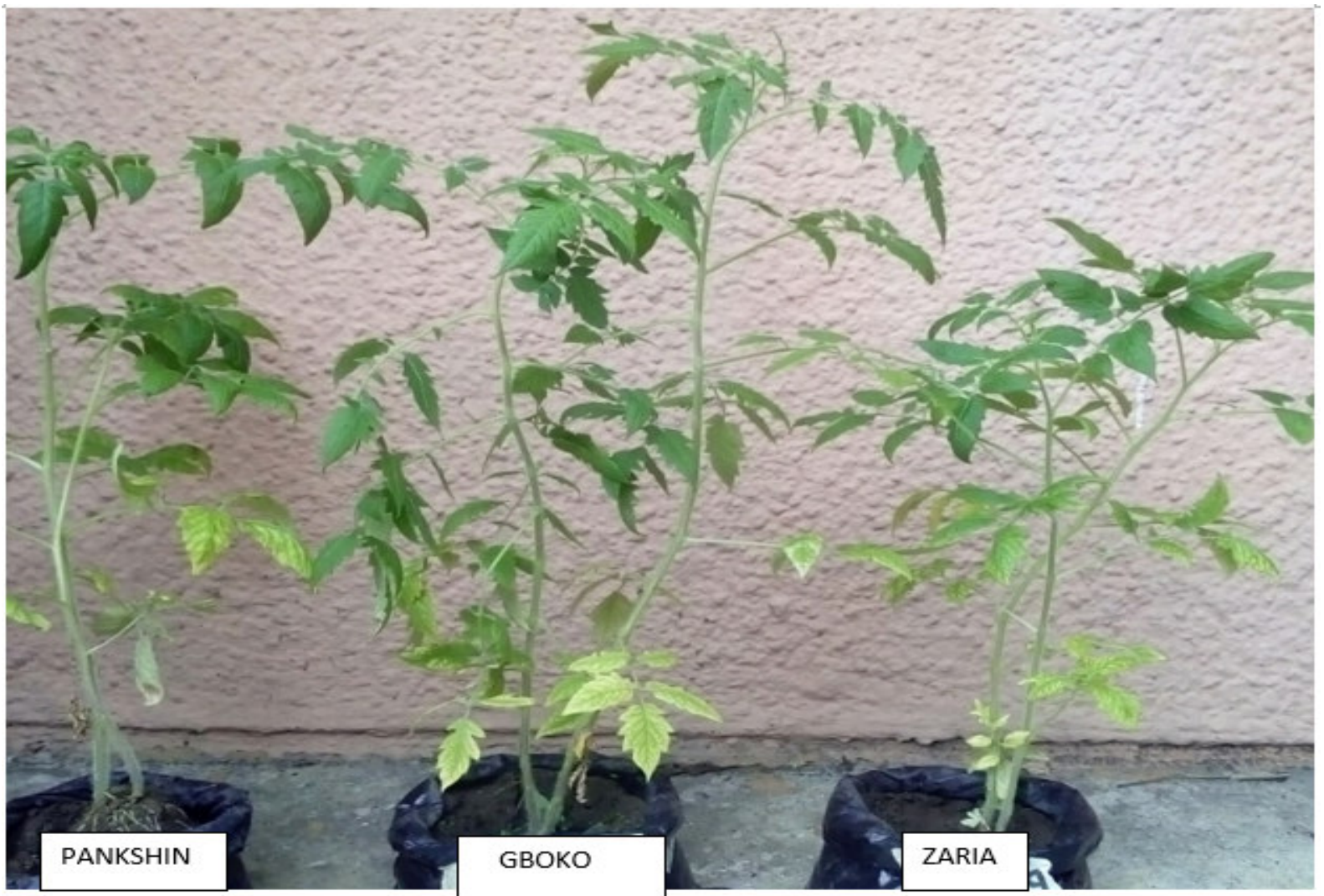

Fig. 3: Plant of the three varieties

Zaria variety also showed significant difference in leaf area across the different watering regimes (Fig.8), but others didn't. Pankshin variety had leaf area values that were significantly higher than those of Zaria and Gboko, but did not vary significantly across the different watering regimes (Fig.11). Leaf area and plant height values show that Pankshin can tolerate a wide range of watering regimes (Figs.6, 7, 10, 11).

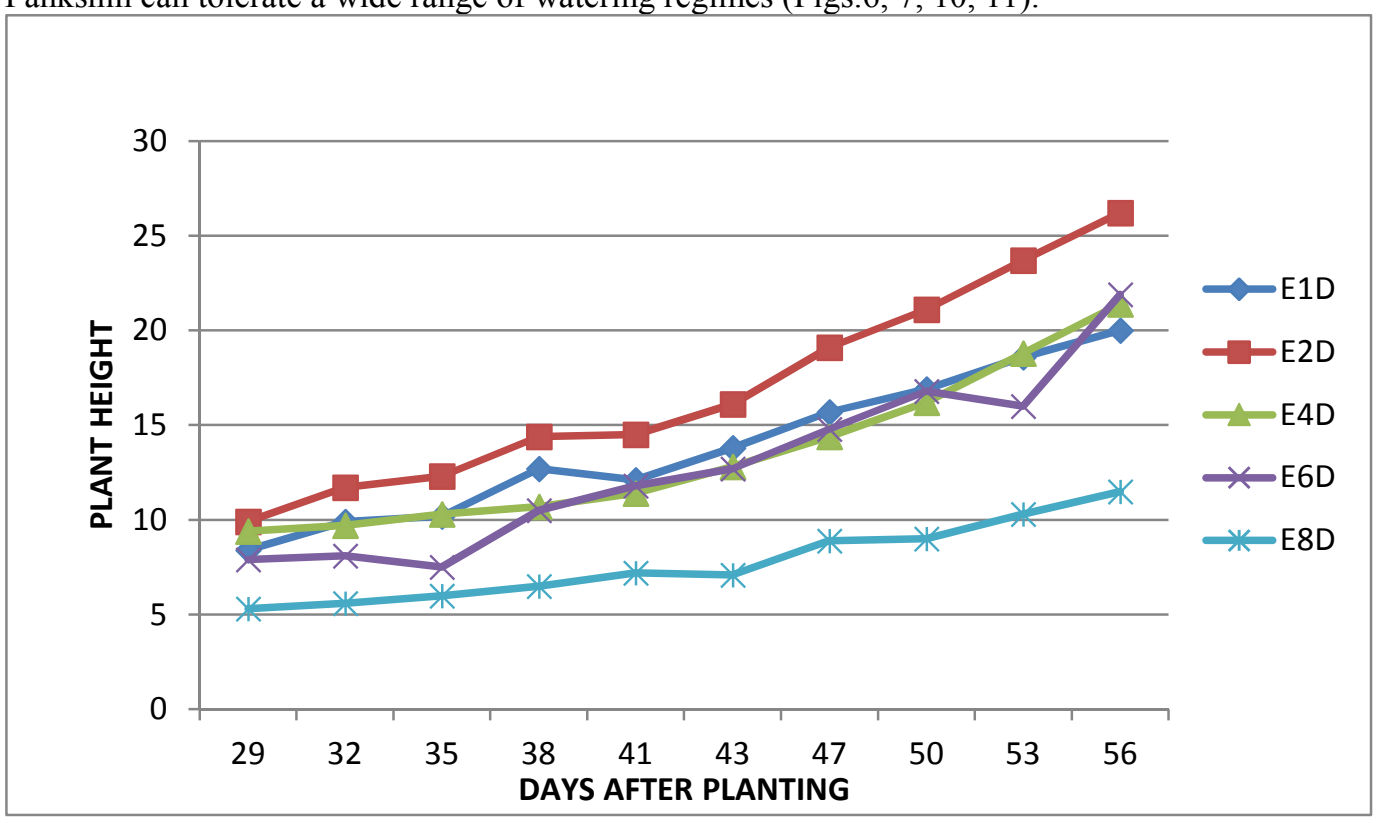

Figure 4: Plant height for Lycopersicum esculentum var. Zaria 


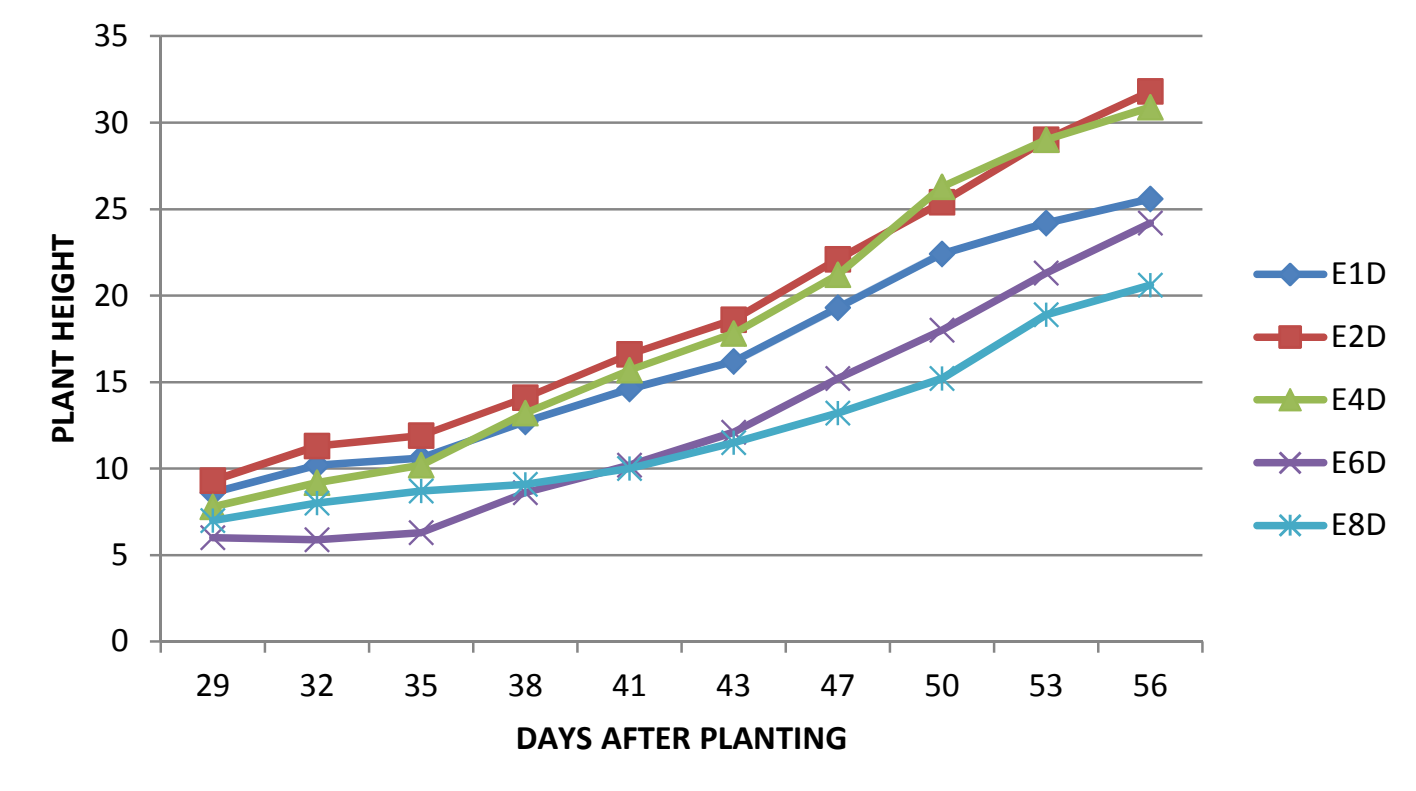

Figure 5: Plant Height for Lycopersicum esculentum var. Gboko

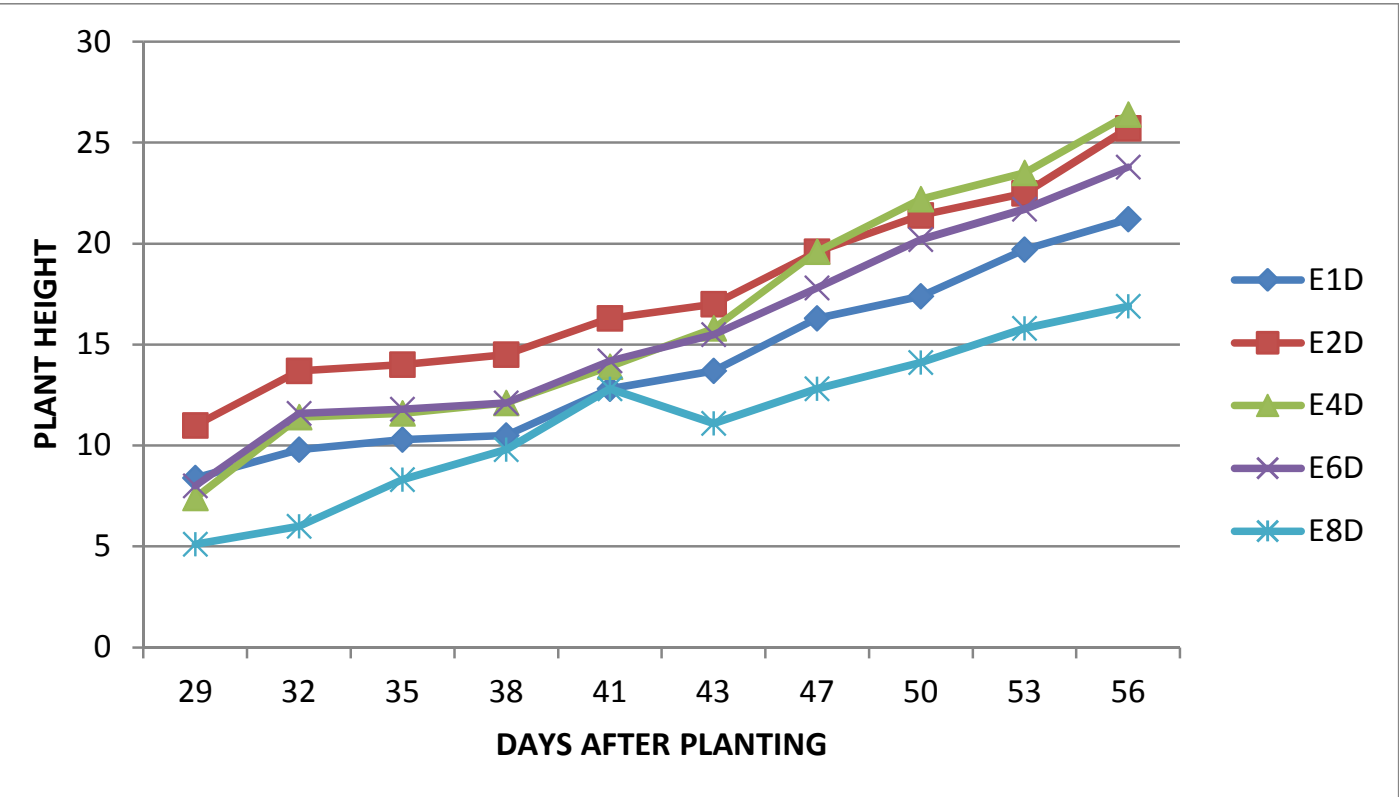

Figure 6: Plant height for Lycopersicum esculentum var. Pankshin 


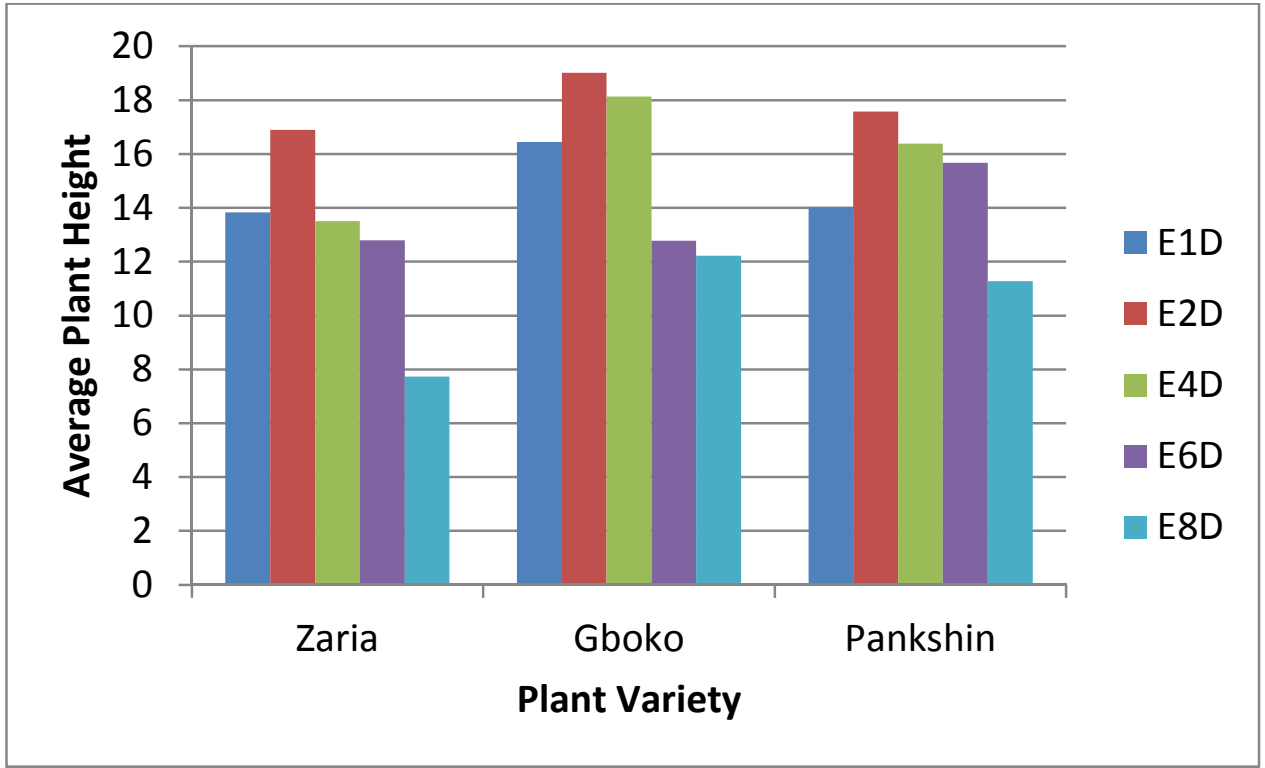

Figure 7: Average Plant Height for the 3 Varieties

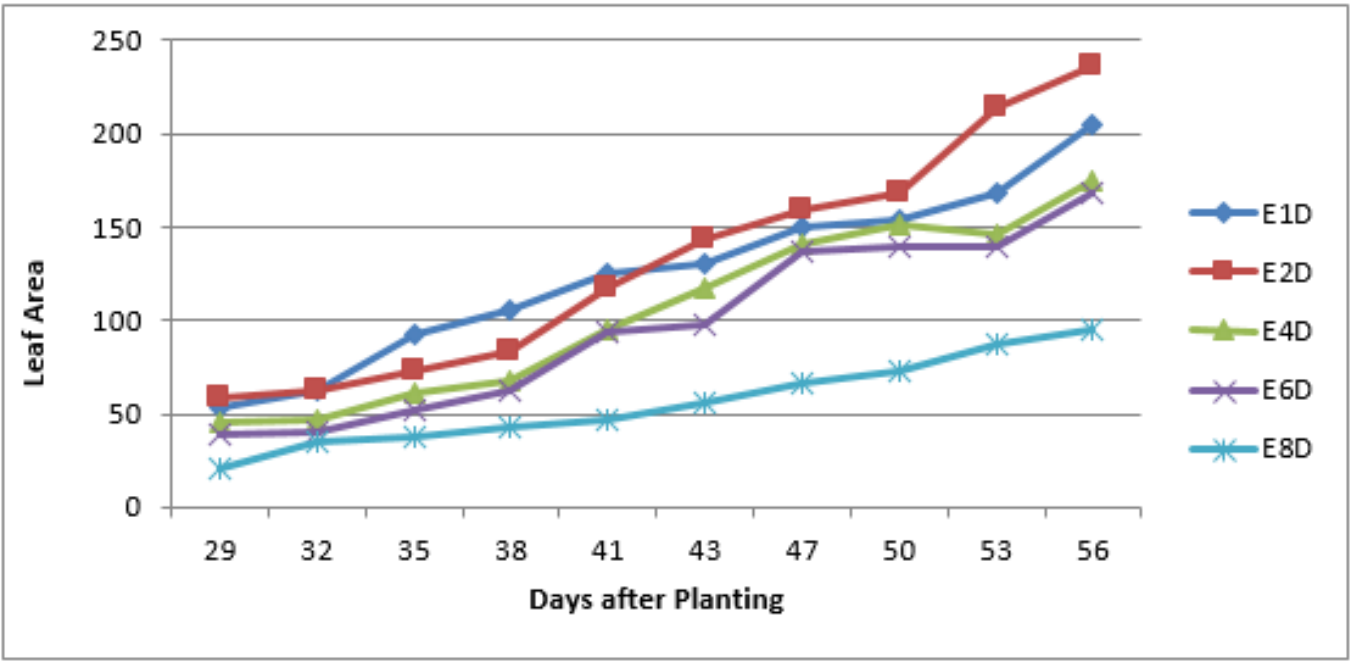

Figure 8: Leaf area graph for Lycopersicum esculentum var. Zaria

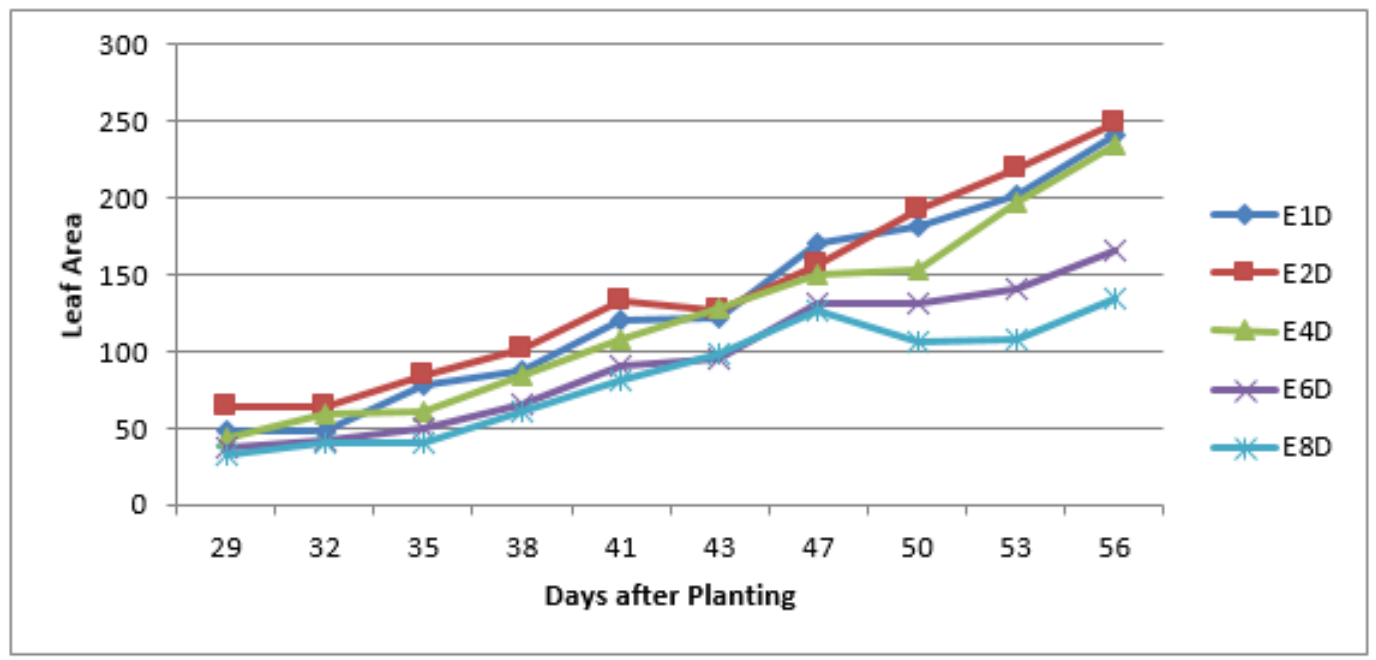

Figure 9: Leaf area graph for Lycopersicum esculentum var. Gboko 


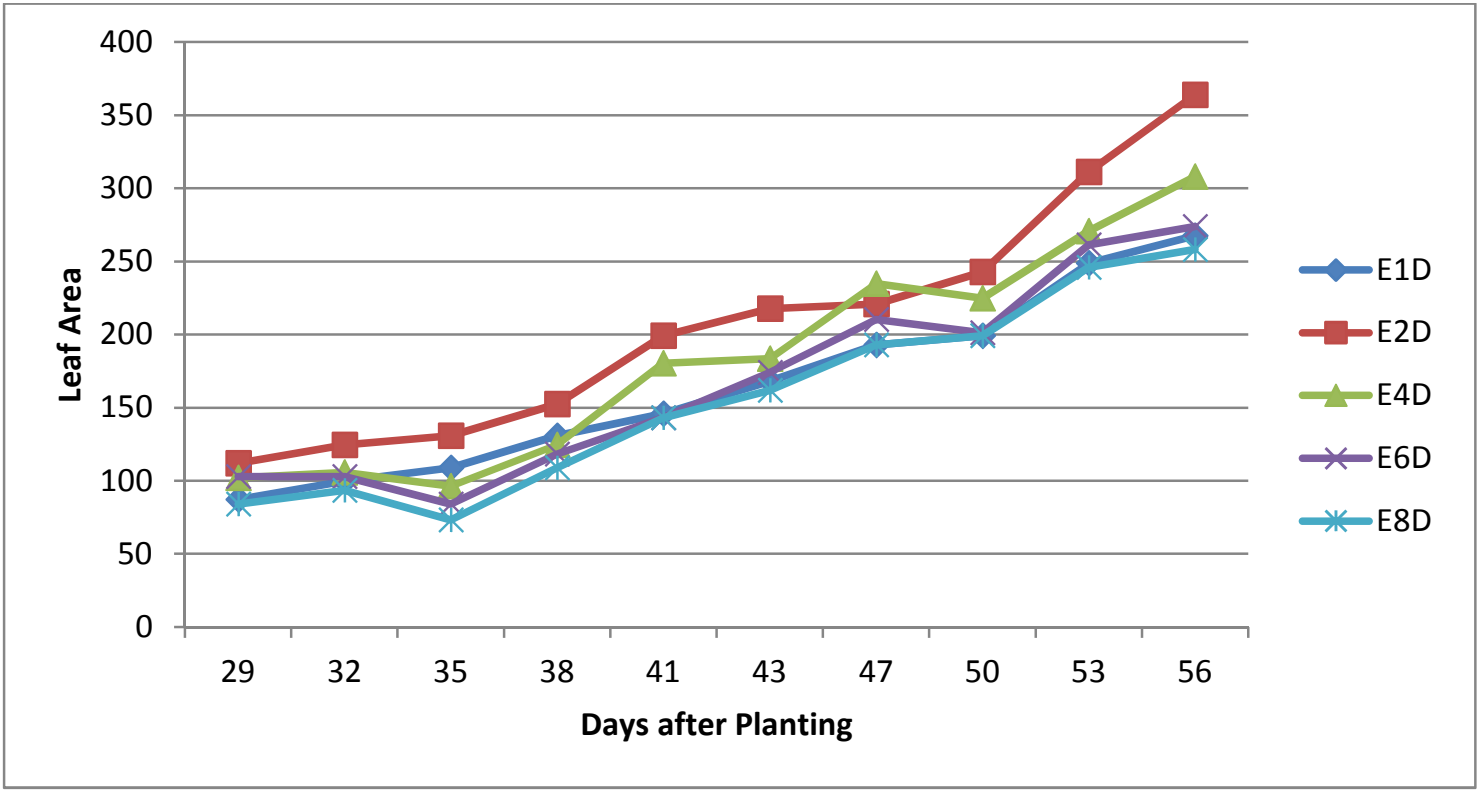

Figure 10: Leaf area graph for Lycopersicum esculentum var. Pankshin

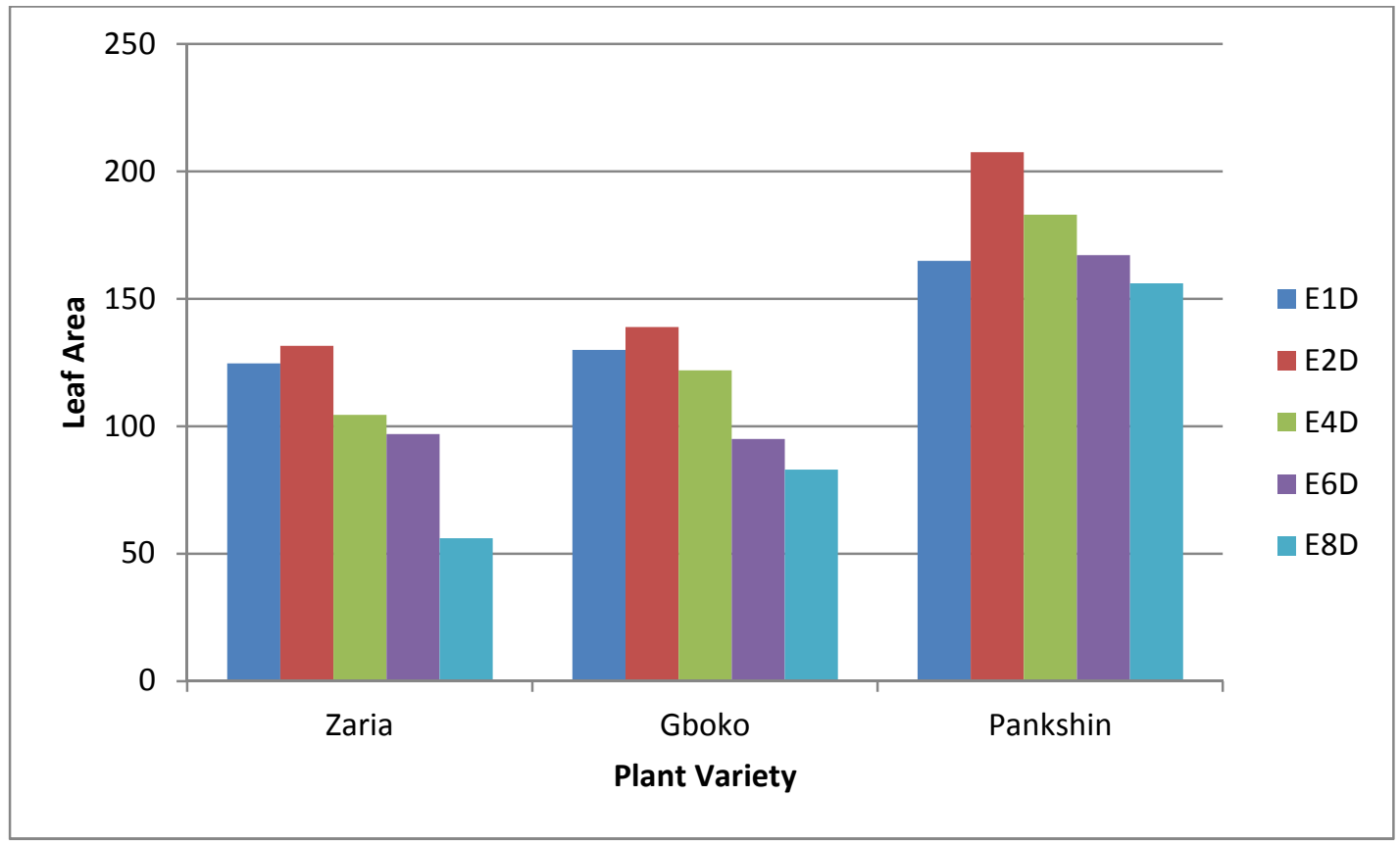

Figure 11: Average Leaf area for the 3 Varieties

\section{Discussion and Conclusion}

Tomato water requirement is influenced by crop variety, soil type, soil moisture regime, physiological and environmental factors (Oiganji et al., 2013). The Pankshin variety which produces the biggest fruits of the three varieties had the highest leaf area (Fig.11). It was the most tolerant in performance with different watering regimes -E2D to E8D watering. Pankshin variety is planted in the northern part of the country usually towards the end of January to February at a temperature range of $23-40.8^{\circ} \mathrm{C}$. This variety of tomato however, has a lower growing rate in terms of flowering percentage and fruit yield than the Zariaseed and Gbokoseed (Ahmad and Singh, 2005). It is also planted during the later dry season of the year around October - November (Ahmad and Singh, 2005). Pankshin is the best tomato; while others are green during the rainy season, Pankshin is red, big, strong, produce more puree than the other two, and expensive (Olaniyi et al.,2007).

Although the three tomato varieties fall almost within the same agro-ecological and climatic zone, Pankshin grows at the Jos plateau area with its characteristic climate. This could account for the significantly higher leaf area index recorded for this variety compared to others (Fig. 11). 
Zaria and Gboko varieties are physiologically similar, but the Zaria variety is more selective in water requirement as there is significant difference in both plant height and leaf area with the different watering regimes. The Zaria variety didn't do well at "E8D" (Fig. 4 and 8). Zaria seed appears to grow faster between the heat periods of January to March at a mean minimum temperature of $22.3^{\circ} \mathrm{C}$ and mean maximum temperature of $40.6^{\circ} \mathrm{C}$. Under this condition, this variety tends to develop or grow faster in terms of flowering percentage and fruit yield. Geographically speaking this variety is cultivated in the northern part (Kano, Kaduna, Zaria and Minna) of the country. This variety gives a high fruit yield during the dry season of the year and it is also responsible for the high availability of local tomato at the local market during this time, making cheap and affordable good quality tomato from January to March period of each year (Olaniyi and Fagbayide, 1999). The Zaria iron seed have thick skin, meaty pulp and less juicy, so they are ideal for bottling or making pastes or sauces.

Gboko variety was not selective in water requirement as the plant height and leaf area showed no significant difference between treatments. Gboko seed is planted in the middle - belt (Kogi and Benue). It grows faster between April to July at a mean minimum temperature of $25.6^{\circ} \mathrm{C}$ and a mean maximum temperature of $40.8^{0} \mathrm{C}$ (Agele et.al., 2002).During this period, it has a high flowering percentage which also leads to high fruit yield. It is also grown during the heat period of the dry season toward the late months of the year and contributes significantly to the availability of tomato in our local market around January - February. Gboko seed gives a medium fruit size. It's oblong in shape and contains more moisture and less pulp/puree.

Considering the fact that these tomato varieties are harvested during the dry season, it is obvious that they were grown by irrigation in their various places in the northern part of the country. Watering the tomato plants by irrigation from "E4D" to "E6D" would give good yield economically, although "E2D" watering seems to be the ideal from this study, for these varieties.

It is also obvious from this study that the climate of the area where tomato is planted has some effect on both its genetic makeup and physiology. The production of commercial tomato is influenced by both genetic and environmental factors such as soil, climate, water and crop management (Kuscu, et al., 2014). In other words, there is variety $\mathrm{x}$ environment interaction. This can be seen in the leaf area and morphology of Pankshin variety which is grown in the Jos plateau area. There is also the higher pulp content of its fruit. The climatic parameters here would include rainfall, relative humidity, temperature and sunlight. There appears to be a relationship between growths, climatic conditions of tomato, pulp content, moisture content and water requirement.

Although Pankshin variety (also called "UTC") is known to be the best tomato variety, especially for its high pulp content, large size and low moisture content, however it is only available in the market during the dry season from February and starts disappearing from April, though it is the most desired.

Tomato is an important part of the human diet and has gained wide use in every Nigeria home. During the rainy season, its affordability drops drastically, and only watery varieties with poor puree/pulp content are available, so people resort to consuming the processed products such as tomato paste, juice, puree and ketchup. Over $80 \%$ of tomato consumption comes from these processed products (Takeoka et al.,2001), but nutritionally, tomato is better consumed fresh.

According to Grubben and Denton (2004), Nigeria ranked highest in Africa in terms of tomato production $(879,000$ t/annum). However, today, it's no news that we are not meeting up with our tomato consumption needs especially with the recent epidemic of tomato disease popularly known as "tomato Ebola" which is caused by tomato leaf miner.

It is therefore recommended that in addition to the results of this study, if all the growth requirements of the Pankshin variety could be more thoroughly investigated, they could be simulated under greenhouse conditions in different parts of the country. This way, this variety could be grown all year round, and we wouldn't have to wait till the dry season to have good quality tomato for consumption.

\section{References}

Abdel-Razzak, H., Wahb-Allah, M., Ibrahim, A., Alenazi M. and Alsadon, A. (2016) Response of Cherry Tomato to Irrigation Levels and Fruit Pruning under Greenhouse Conditions. J. Agric. Sc. Tech. Vol. 18, Issue 4:1091103

Adekiya, A., and Agbede, T. (2009) Growth and yield of tomato (Lycopersicon esculentum mill) as influenced by poultry manure and NPK fertilizer. Emirates Journal of Food and Agriculture, 21(1): 10-20.

Akanni, D.I. and Ojeniyi, S. O. (2007). Effect of different levels of poultry manure on soil physical properties, nutrient status, growth and yield of tomato (Lycopersicon esculentum). Research Journal of Agronomy, 1: 14.

Agele, S.O., Iremiren, G. O. and Ojeniyi, S.O. (1999). Effects of plant density and mulching on the performance of late-season tomato (Lycopersicon esculentum) in southern Nigeria. J. Agric. Sci. 133: 397-402

Agele, S.O., Olufayo, A. and Iremiren, G. O. (2002). Effects of season of sowing on water use and yield of tomato in the humid south of Nigeria. African Crop Sci. J., 10: 231-237

Ahmad, A. and Singh, A. (2005). Effects of staking and row-spacing on the yield of tomato (Lycopersicum 
lycopersicum Mill.) cultivar Roma VFn the Sokoto Fadama, Nigeria. Nig. J. Hortic. Sci. 10: 94-98.

Ewulo, B. S., Ojeniyi, S. O., Akanni, D. A. (2008) Effect of poultry manure on selected Soil physical and chemical properties, growth, yield and nutrient status of tomato. African Journal of Agricultural Research. 2008;3(9):612-16.

Grubben, G. J. H. and Denton, O. A. (2004) Eds. Plant Resources of Tropical Africa 2: Vegetables. PROTA Fpundation, Wgeningen, Netherlands/Backluys Publishers, Leidin, Netherlands/CTA Wageningen, 63-176. Hardie D (1999): Antivitral ch

Kuscu, H., Turhan, A. and Demir, A. O. (2014) The response of processing tomato to deficit irrigation at various phenological stages in a sub-humid environment. Agricultural Water Management 133: 92-103

Odeleye, F. O. and Odeleye, M. O. (2001). Evaluation of morphological and agronomic characteristics of two exotic and two adapted varieties of tomato (Lycopersicon esculentum) in South West Nigeria. Proceedings of the 19th Annual Conference of HORTSON. (1):140-145.

Oiganji, e., Jane, O.I. and Sanusi, H. O. (2013) Vegetative Growth and Yield of Tomato as Affected by Water Regime and Mulching. Prod, Agric. and Tech. 9(2): 43-53

Oladitan, T. O. and Oluwasemire, K. O. (2018) Influence of weather condition on selected tomato varieties in response to season of sowing in Akure, a rainforest zone of Nigeria. Art Human Open Acc. J. 2(6): 422-426

Olaniyi, J. O., Akanbi, W. B., Adejumo, T. A. and Akande, O. G. (2007) Growth, fruit yield and nutritional quality of tomato varieties. African Journal of Food Science 4(6):398-402.

Olaniyi, J. O. and Fagbayide, J. A. (1999). Performance of eight Fl Hybrid Cabbage (Brassica olerácea L.) varieties in the Southern Guinea Savanna zone of Nigeria. J. Agric. Biotechnol. Environ., 1: 4-10

Ploeg, A. \& E. Heuvelink, (2005). Influence of sub-optimal temperature on tomato growth and yield: A review. J. Hortic. Sci. Biotechnol., 80:652-659.

Takeoka, G. R., Dao, L., Flessa, S., Gillespie, D. M., Jewell, W. T., Huebner, B., Bertow, D. and Ebeler, S. E. (2001) Processing effects on lycopene content and antioxidant activity of tomatoes. J. Agric. Food Chem. 49(8): 3713-3717.

Turhan, A., Kuscu, H., Ozmen, N., Aydinol, P., Seniz, V. and Demir, A.O. (2016). Effects of soil water deficit at different growth stages on yield and quality of processing tomato. Acta Hortic. 1145, 85-92 